\title{
Piezometric Behavior in the Amazonian Lateritic Plateaus: Implications of Climate Changes to the Recharge of the Alter do Chão Aquifer System
}

\author{
Júlio Henrichs de Azevedo ${ }^{1,2 *}$, José Eloi Guimarães Campos ${ }^{1}$, André Walczuk Gomes ${ }^{1}$ \\ ${ }^{1}$ Institute of Geosciences, Universidade de Brasília, Campus Darcy Ribeiro, Brasília, Brazil \\ ${ }^{2}$ Instituto Brasileiro do Meio Ambiente e dos Recursos Naturais Renováveis, SCEN Trecho 2-Edifício Sede, Brasília, Brazil \\ Email: ‘julio.henrichs@gmail.com, eloi@unb.br,walczuk.andre@gmail.com
}

How to cite this paper: de Azevedo, J.H., Campos, J.E.G. and Gomes, A.W. (2020) Piezometric Behavior in the Amazonian Lateritic Plateaus: Implications of Climate Changes to the Recharge of the Alter do Chão Aquifer System. Journal of Water Resource and Protection, 12, 102-119. https://doi.org/10.4236/jwarp.2020.122007

Received: September 30, 2019

Accepted: January 17, 2020

Published: January 20, 2020

Copyright $\odot 2020$ by author(s) and Scientific Research Publishing Inc. This work is licensed under the Creative Commons Attribution International License (CC BY 4.0).

http://creativecommons.org/licenses/by/4.0/

\section{(c) (i) Open Access}

\begin{abstract}
Potentiometric and pluviometric datasets were evaluated to understand the behavior of aquifer recharge in the bauxite plateaus in the Porto Trombetas region, Pará, Northern Brazil. The datasets are originated from three monitoring wells and an automatic climatological station. The local groundwater is related to the Alter do Chão Aquifer System, which despite being unconfined in valley regions, is semiconfined in the plateaus areas. The aquifer recharge occurs by direct infiltration and by leakage from the aquitard in the unconfined and semiconfined portions, respectively. Precipitation declined by 27\% between 2002 and 2017. The rains accumulated between February and April are the most important for the recharge processes since this period is marked by higher absolute precipitation (up to $300 \mathrm{~mm} / \mathrm{month}$ ) and less deviation from the historical pattern. The recharge measured by the annual fluctuation of the water table also declined significantly in the 2010-2016 period. Statistical analysis demonstrates that in the case of a permanent climate change, expressed by rainfall reducing, the aquifer recharge would diminish at a non-linear rate, which is also expected for the base flow rates. In addition, data evaluation reveals that deforestation intensely decreases the recharge rates, as observed in the Aviso Plateau mining site. The results demonstrate that the water table fluctuations must be considered when modeling Global Climate Changes since the maintenance of surface flow rates (springs, lakes and streams) depends on aquifers baseflow. The result of the statistical analysis can be also applied to regions where climate patterns are strong seasonal, as the Savannah of Central Brazil.
\end{abstract}

\section{Keywords}

Groundwater, Alter do Chão Aquifer System, Amazon Region, Climate Change 


\section{Introduction}

Groundwater hydrodynamic processes represented by recharge, storage, transmission and aquifers discharge are responsible for regulating surface water systems [1]. In times of drought, groundwater discharges as subsurface flow, interflow and baseflow, contribute to maintaining the surface water bodies (springs, lakes, streams and rivers) [2].

Groundwater systems assume strategic importance due to the geological exploitation potential or surface water interface in the case that the projections about Global Climate Change (GCCs) are confirmed [3]. Another important aspect of aquifer discharge is related to the quality of water since aquifers are represented by geological materials (soil, saprolith, and rock) that play an important role in functioning as filter [4] [5] [6].

Green, T.R. et al. [7], Smerdon, B. D. [8], and Dragoni, W. et al. [9] discuss about the potentially negative environmental impacts of the GCCs on recharge and base flow rates, as well as on water from the quantitative and qualitative point of view. However, these authors are unanimous to indicate the need for developing further studies, including a multidisciplinary approach. Zhang, E. et al. [10] discuss the water transfer by interflow and baseflow is an important indicator of the vulnerability of water resources to global climate changes.

In Africa, Anyah, R. O. et al. [11] dealt with the relationship between climate change and storage of water resources, which can be either linear or nonlinear, depending on the particularities of hydroclimatologic features, hydrological subsurface processes and land use activities. Hirata, R. et al. [3] argue that, despite many forecasts pointing out to an increasing rainfall, the distribution patterns are going to be more irregular. The simultaneous evaluation of recharge pulses and isolated rainfall events shows that the percentage of what effectively becomes recharge varies systematically according to the characteristics of the rainfall event [13] [14] [15] [16]. This indicates that the climate change scenario can influence significantly the aquifer water supply. Likewise, Nimmo, J.R. et al. [15] argue that increasing average intensity of rain events can either increase or reduce the rate of recharge, due to fill pre-storm soil water deficit or providing runoff facilitation.

After Hirata, R. et al. [3] concern about aquifers recharge in the North and Northeast regions of the Brazil, the Alter do Chão Aquifer System, defined as the second groundwater reservoir in the country (after the Guarani Aquifer System, [17], should be thoroughly investigated in face of the possibly changing pluviometric regime in the Amazonia.

Thematic research involving Amazonia is generally directed to greenhouse gas emissions caused by deforestation and slash-and-burn areas conversion, as well as to possible changes in the rainfall regime [18] [19] [20]. However, the number of studies aimed at investigating the behavior of the water regime in this region is still reduced [21] [22], particularly those incorporating the hydrogeology.

The limitations for obtaining extensive climate data series, the difficulties for 
establishing future projections for land use, the lack of data on aquifer hydrodynamics, the complexity of validating prediction models, and the reduced model ability for considering the associated interdisciplinary problems culminate with high degrees of uncertainty, thus becoming the main obstacles for researching the effects of the GCCs on hydrogeology, particularly, on aquifer recharge processes [7] [23] [24] [25].

In view of the strategic role played by the Alter do Chão Aquifer in the Amazon region and the insufficient research towards integrating hydrogeological and climatic studies, this paper aims to describe the aquifer recharge behavior in the lateritic plateaus, for a possible changing scenario regarding to rainfall regime.

\section{Hydrogeological and Climate Setting}

The Alter do Chão Aquifer System, related to the homonymous geological formation, is an important component of the Hydrogeological Amazonas Province [26], with approximately $300.000 \mathrm{~km}^{2}$ outcrop area, partially located in the States of Pará, Amazonas, and Amapá ([27] [28] [29]. It consists of an exposed area that continues underground to the West, under the Içá and Solimões formations [30]. The Alter do Chão Formation is represented by the fluvio-lacustrine and fluvial deposits of Cenozoic age [31], consisting of medium to coarse sandstone with clay fragments, medium to coarse caulinitic sandstone, fine sandstone, massif mudstone interbedded with thin to medium sandstone and mudstone. The thickness varies from tens to hundreds of meters up to 600 meters in the depositional centers [32] [33] [30].

The hydrogeological potential of the Alter do Chão Aquifer System is defined by these geological features and the regional climate pattern. The groundwater reserve is approximately $86,550 \times 10^{6} \mathrm{~m}^{3}$, and the annual recharge is about $226 \times$ $10^{6} \mathrm{~m}^{3}$ [34] [35] [36] [37] [30].

The regional climate pattern presents isohyet varying from 1800 to $2000 \mathrm{~mm}$ annually [38] [39] distributed in the rainy season that lasts from December to June and the dry season between July and November. The average annual temperature remains around $26^{\circ} \mathrm{C}$. Although November is the hottest month and July the coldest, historically the variations between temperatures of these months do not usually exceed $4^{\circ} \mathrm{C}$ [38].

This climate characterized as tropical humid allows the entire region to be covered by a dense rain forest, even in areas with less naturally fertile soil, thus contributing to the aquifer recharge.

The same regional climate pattern is observed in the study areas. However, the aquifer occurs under lateritic plateaus distributed in the Amazon plain, whose profiles, from the top to the base, include yellow oxisol horizon, iron and aluminum crusts, bauxite horizon, and silt-clay layer (mottled clay). This multilayer set [40]-[45] shows aquitard properties so that in the plateau areas the aquifer is classified as semiconfined type.

The analysis of data obtained at a local meteorological station, for the period 
of 2002 to 2017, indicates annual averages of $2111.40 \mathrm{~mm}$ for precipitation and $27.1^{\circ} \mathrm{C}$ for temperature. Figure 1 illustrates the rainfall distribution regime during that same period, as well as those accumulated each month.

The water balance, obtained for the set of climatic data from 1961 to 1990 for the Óbidos Station (Pará State), demonstrates that the surpluses occur from February to July, with March the month characterized by higher volumes of water in the soil, occurring water deficit between August and December, where September is the most critical month [46].

\section{Material and Methods}

\subsection{Study Areas and Research Sites}

The piezometric and meteorological monitoring datasets used in the analysis were produced by the Rio do Norte Mining Company (MRN) as a requirement for obtaining the environmental license for the bauxite mining projects in the lateritic plateaus of the Saracá-Taquera National Forest (Figure 2). The National Forest is a sustainable conservation unit, where the mining operation is allowed, located in Porto Trombetas, Oriximiná County, in the state of Pará.

Two of the piezometric monitoring sites are distributed in areas without significant anthropogenic changes, characterized by the dense rain forest coverage of the low Amazon plateaus [47] [48] [49] [50]. Despite the same context, the third site is located in an area affected by mining activity, but currently undergoing an environmental recovery process. The bauxite ore extraction includes main operations such as deforestation of natural forest; removal of barren material and organic soil; excavation, loading and ore transport; and environmental recovery of the affected area, consisting of replacement of the barren material and organic soil, topographic regularization, and reforestation [43]. Table 1 shows the study sites, the dimensions and the main features of land use and natural cover.

The monitoring wells, specifically built for piezometric measurements and water sampling for hydrochemical studies, are 102 meters deep and have a PVC cased-screen column in the entire borehole. The screen section is limited to 6 meters at the bottom, and then a gravel pack is positioned in the column space between the case-filter and the borehole (Figure 3). At the upper portion, there

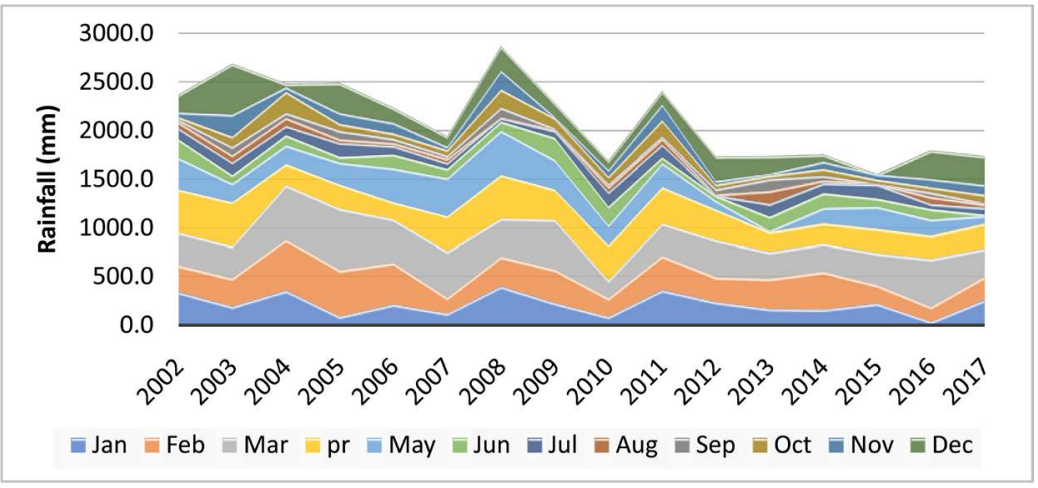

Figure 1. Annual rainfall and accumulated monthly rainfall. 


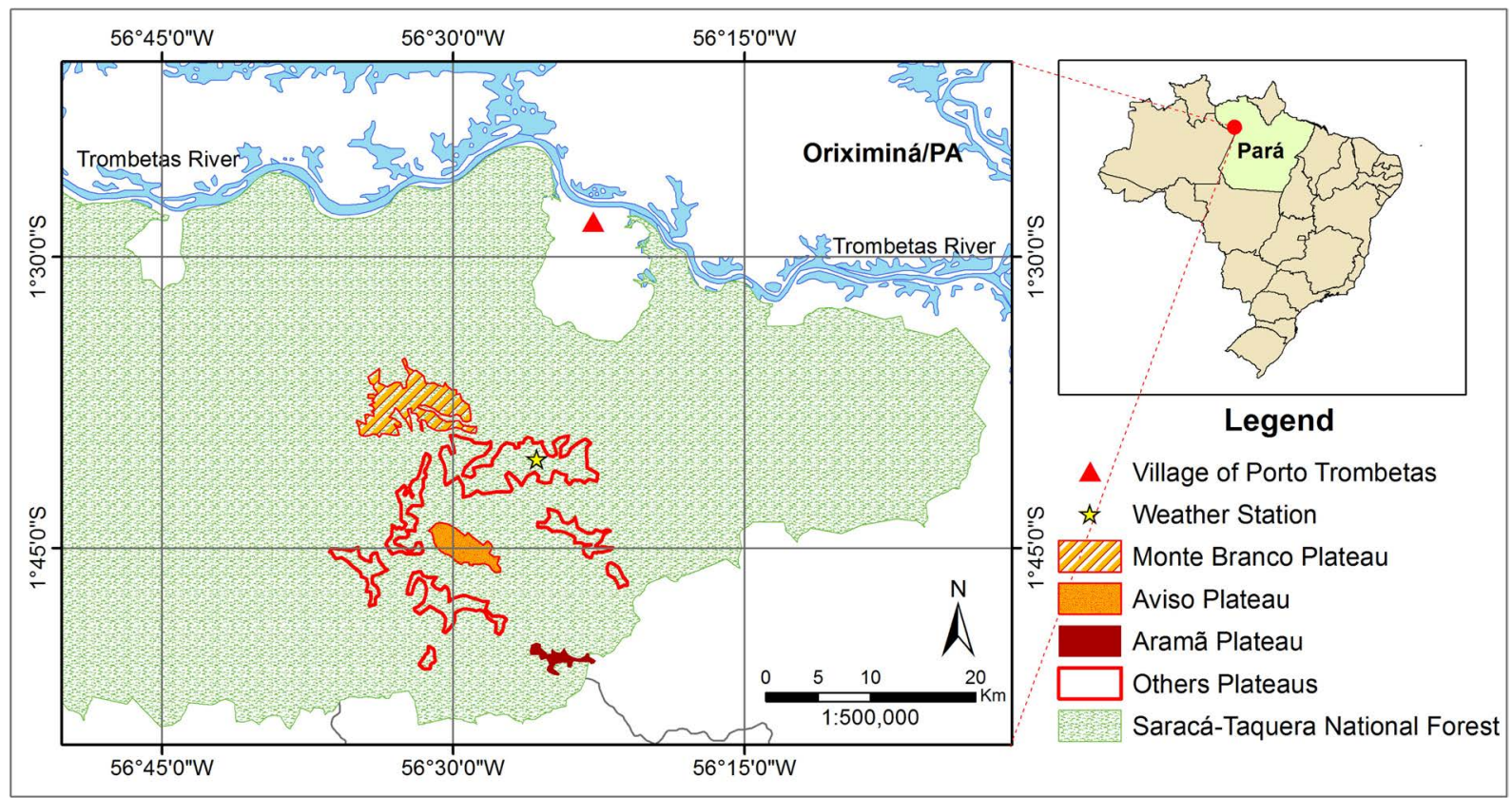

Figure 2. Map showing the three studied lateritic plateaus. Anthropic interference is more significant over the Aviso Plateau area.

Table 1. Monitoring sites characteristics.

\begin{tabular}{ccccccc}
\hline Site & Altitude $(\mathrm{m})$ & Lat S & Long W & Plateau & Area (ha) & Characteristic \\
\hline W-MB & 191.00 & $01^{\circ} 37^{\prime} 26^{\prime \prime}$ & $56^{\circ} 32^{\prime} 05^{\prime \prime}$ & Monte Branco & 3750 & Amazon rainforest cover \\
W-AV & 159.00 & $01^{\circ} 45^{\prime} 14^{\prime \prime}$ & $56^{\circ} 30^{\prime} 07^{\prime \prime}$ & Aviso & 1400 & Mine in environmental recovery process \\
W-AR & 139.00 & $01^{\circ} 50^{\prime} 20^{\prime \prime}$ & $56^{\circ} 26^{\prime} 10^{\prime \prime}$ & Aramã & 375 & Amazon rainforest cover \\
\hline
\end{tabular}

(W-Deep Wells; MB-Monte Branco; AV—Aviso; AR-Aramã).

WELL PROFILE

$$
\frac{0.0 \mathrm{~m}}{5.0 \mathrm{~m}}
$$

$10 . \mathrm{m}$

$30.0 \mathrm{~m}$

$85.0 \mathrm{~m} \stackrel{\text { Static level }}{\nabla} 87.3 \mathrm{~m}$
$\frac{100.0 \mathrm{~m}}{102.0 \mathrm{~m}}$

Figure 3. Schematic profile showing constructive and lithological logs (adapted from [51]).

LITHOLOGY

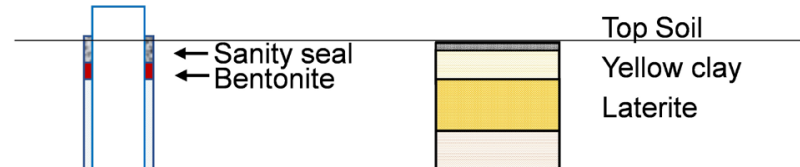

Variegated clay

Compacted sand

Friable sandstone
Journal of Water Resource and Protection 
is a 5-meter sanitary seal. This well design ensures that the assessed waters are from the deep aquifer, related to the semiconfined portion of the Alter do Chão Aquifer System.

\subsection{Procedures}

The piezometric monitoring included a monthly data series from January 2010 to December 2016, measured with an electric level meter. To minimize possible problems related to data quality, common in monitoring datasets produced by non-automated tools, the following procedures were adopted: removing measures notably characterized as typos and outliers defined as the result of the mean \pm two times the standard deviation; and, performing the control measures in April 2016. The control measurements resulted in data similar to those listed in the monitoring series for that same month (differences of $\sim 0.2$ meters).

The study of hydrodynamic behavior of the aquifers is based on analyzing the potentiometric data given by the distance from the surface to the water level that represents the water table or the hydraulic head at each measurement point. The annual water table fluctuation (WTF) method, in which the seasonal variation of water level in the wells represents the rainwater contributions to the saturated zone of the aquifer system, was employed for evaluating the recharge. This method was proposed by [15] [52] for cases in which the annual monitoring piezometric series are available and provide good estimation of the actual recharge since it identifies the portion of infiltration water that, minus the evapotranspiration and interflow losses, effectively reaches the saturated zone.

Nimmo, J.R. et al. [15] defined that the annual recharge rate is expressed as the difference between the minimum and highest potentiometric level $(\Delta \mathrm{h})$, obtained in the period defined by the groundwater rise curve during the year. Larger or smaller recharge rates are represented by increasing or decreasing values of $\Delta \mathrm{h}$, respectively.

The precipitation data are obtained from automated weather station records operated by MRN in the Saracá Plateau. The present analysis employed data from 2002 to 2017 to assess the variability of rainfall in recent years and from 2010 to 2016 for comparing with the piezometric data.

Statistical treatments consisted of analysis of variance (ANOVA) to compare the means, and Tukey method for testing variability, trend analysis of time series and cross-correlations.

\section{Results}

\subsection{Rainfall}

Although the mean annual precipitation did not vary significantly in the study areas for the 2002-2017 period (Table 2) according to ANOVA with 95\% reliability $\left(\mathrm{P}\right.$-value $\left.=0.76 ; \mathrm{F}=0.72 ; \mathrm{F}_{\mathrm{CRITICAL}}=1.72\right)$, the trend analysis (Figure 4 ) assuming a Mean Absolute Percentage Error (MAPE) up to $10 \%$, indicated that rainfall tends to decrease over time. However, this tendency had some atypical 
Table 2. Monthly and accumulated precipitation, in $\mathrm{mm}$, for the study area (2002-2017). Data obtained from the automated weather station owned by MRN.

\begin{tabular}{|c|c|c|c|c|c|c|c|c|c|c|c|c|c|}
\hline \multirow{2}{*}{ Year } & \multicolumn{12}{|c|}{ Rainfall (mm) } & \multirow{2}{*}{ Total } \\
\hline & Jan & Feb & Mar & Apr & May & Jun & Jul & Aug & Sep & Oct & Nov & Dec & \\
\hline 2003 & 191.0 & 290.6 & 332.2 & 449.8 & 193.5 & 85.6 & 130.2 & 77.4 & 83.8 & 105.0 & 224.8 & 524.0 & 2687.9 \\
\hline 2004 & 358.9 & 523.0 & 559.9 & 215.8 & 193.0 & 103.8 & 95.6 & 85.6 & 51.0 & 214.0 & 47.4 & 35.8 & 2483.8 \\
\hline 2005 & 86.6 & 477.4 & 636.8 & 244.6 & 226.8 & 59.2 & 141.8 & 42.0 & 85.6 & 70.6 & 110.2 & 309.4 & 2491.0 \\
\hline 2006 & 214.4 & 424.4 & 452.0 & 173.8 & 348.6 & 142.4 & 87.4 & 34.2 & 42.2 & 54.4 & 106.6 & 154.8 & 2235.2 \\
\hline 2007 & 119.0 & 163.2 & 476.2 & 362.4 & 391.2 & 95.8 & 59.6 & 47.4 & 29.2 & 58.4 & 33.0 & 107.0 & 1942.4 \\
\hline 2008 & 402.5 & 302.2 & 393.4 & 445.6 & 457.4 & 94.2 & 37.6 & 8.2 & 99.8 & 183.8 & 192.6 & 250.6 & 2867.9 \\
\hline 2010 & 85.0 & $192.8^{*}$ & 183.6 & 363.5 & 205.6 & 190.6 & 149.0 & 55.8 & 30.0 & 71.8 & 68.6 & 94.6 & 1498.1 \\
\hline 2011 & 364.3 & 348.2 & 335.4 & 371.8 & 248.4 & 58.6 & 131.6 & 64.0 & 21.6 & 166.0 & 161.6 & 135.2 & 2406.7 \\
\hline 2012 & 238.0 & 255.8 & 382.4 & 313.2 & 92.0 & 50.4 & 7.2 & 10.2 & 53.8 & 44.2 & 35.6 & 254.4 & 1737.2 \\
\hline 2013 & 167.2 & 310.6 & 274.4 & 209.8 & 12.0 & 143.0 & 130.9 & 135.4 & 124.6 & 33.2 & 15.4 & 183.2 & 1739.7 \\
\hline 2014 & 160.0 & 389.2 & 290.0 & 212.2 & 155.6 & 152.0 & 104.0 & 30.8 & 46.8 & 67.6 & 72.8 & 76.0 & 1757.0 \\
\hline 2015 & 223.4 & 189.0 & 327.1 & 254.2 & 225.8 & 83.2 & 147.8 & 9.0 & 1.2 & 38.6 & 50.8 & 0.6 & 1550.7 \\
\hline 2016 & 33.0 & 154.6 & 494.0 & 241.8 & 164.8 & 106.8 & 52.2 & 76.2 & 47.2 & 49.0 & 83.2 & 296.0 & 1798.8 \\
\hline 2017 & 260.0 & 240.2 & 286.6 & 262.2 & 79.0 & 10.2 & 70.2 & 39.6 & 11.2 & 83.2 & 98.4 & 297.2 & 1738.0 \\
\hline
\end{tabular}

${ }^{*}$ Data failure filled with nearest pluviometric station data (Porto Trombetas).

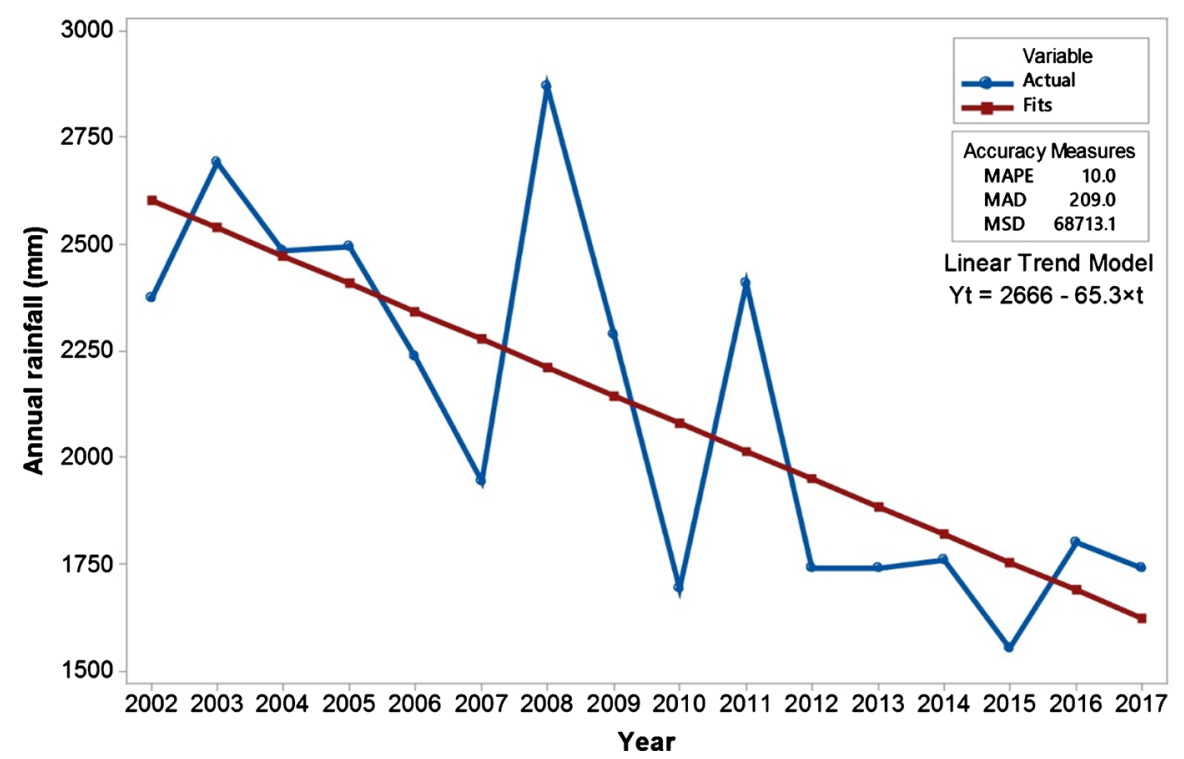

Figure 4. Trend analysis plot for annual rainfall (2002-2017).

years, whose importance is highlighted by the much higher Quadratic Average Standard Deviation compared to the Absolute Average Standard Deviation. The accumulated rainfall decreased by approximately 27\% between 2002 and 2017 . 
Paired comparisons of monthly average rainfall, produced by the Tukey Method with 95\% confidence (Table 3) indicate that February, March and April are the most representative of the rainy season (December to June). However, even within the limits of the first and second quartiles, deviations in rainfall distribution in each of these months can exceed $200 \mathrm{~mm}$ (Figure 5), thus explaining the outliers observed in a few monitoring years. Regardless of climate changes, the data of the studied time series demonstrated a quite variable pattern for the rain distribution.

\subsection{Potentiometry}

The potentiometric data from 2010 to 2016 (Table 4) is significantly different

Table 3. Tukey method for pairwise comparisons of monthly rainfall means (2002-2017). Groups that do not share a letter are significantly different.

\begin{tabular}{cccccccc}
\hline Factor & N & Mean & \multicolumn{5}{c}{ Grouping } \\
\hline Mar & 16 & 392.5 & A & & & \\
Feb & 16 & 304.7 & A & B & & & \\
Apr & 16 & 304.2 & A & B & & & \\
May & 16 & 226.6 & & B & C & & \\
Jan & 16 & 217.3 & & B & C & & \\
Dec & 16 & 190.2 & & & C & D & \\
Jun & 16 & 112.1 & & & & D & E \\
Jul & 16 & 95.7 & & & & D & E \\
Oct & 16 & 85.7 & & & & & E \\
Nov & 16 & 85.0 & & & & & E \\
Aug & 16 & 49.65 & & & & & E \\
Sep & 16 & 47.85 & & & & E \\
\hline
\end{tabular}

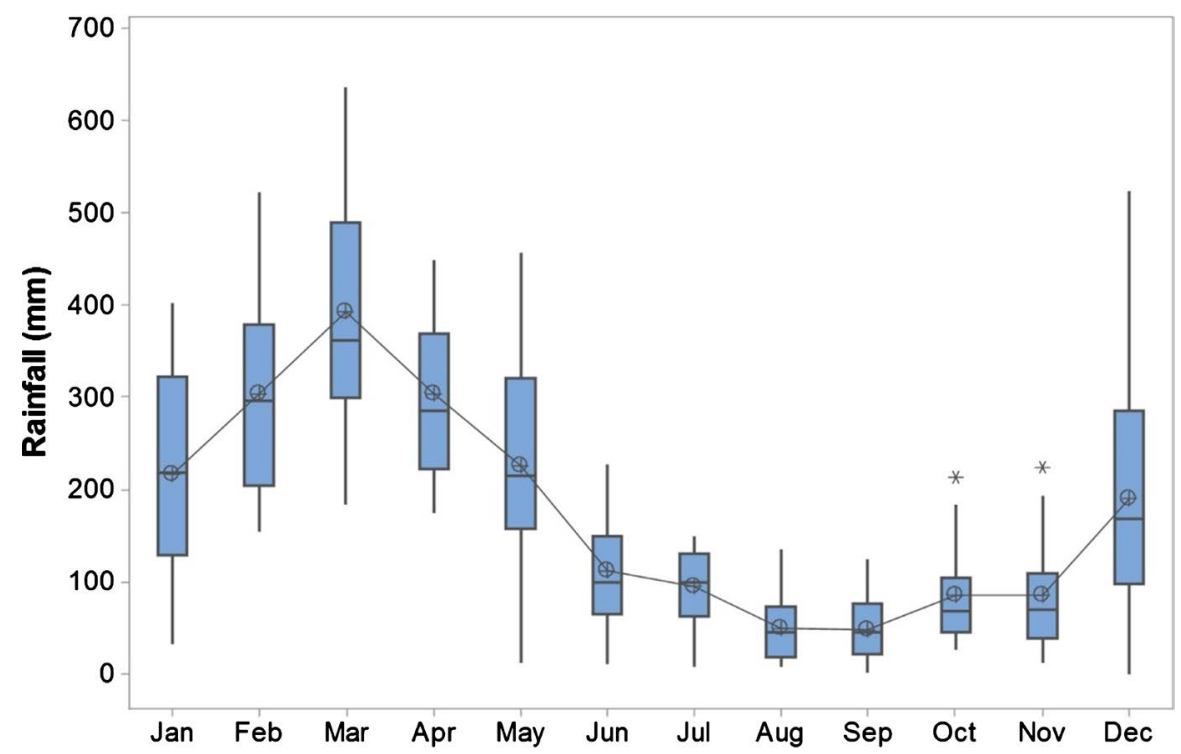

Figure 5. Boxplot of the monthly rainfall over 16 years (2002-2017). 
Table 4. Potentiometry (meters) - 2010-2016 ( $\Delta \mathrm{h}$ is the difference between the highlighted values).

\begin{tabular}{|c|c|c|c|c|c|c|c|c|c|c|c|c|c|}
\hline Sample Sites & Years & Jan & Feb & Mar & Apr & May & Jun & Jul & Aug & Sep & Oct & Nov & Dec \\
\hline \multirow{7}{*}{$\begin{array}{l}\text { Well - Monte Branco } \\
\text { Plateau }\end{array}$} & 2010 & * & 126.9 & 128.1 & 128.0 & 128.6 & 128.5 & 127.6 & 128.3 & 127.5 & 128.7 & 128.5 & 128.9 \\
\hline & 2011 & 128.9 & 125.5 & 125.5 & 126.5 & 128.8 & 127.9 & * & 126.3 & 128.0 & 128.7 & 129.2 & 128.4 \\
\hline & 2012 & 127.5 & 127.2 & 127.3 & 127.7 & 128.5 & 127.9 & 127.6 & 126.0 & 127.8 & 127.8 & 127.0 & 127.1 \\
\hline & 2013 & 127.5 & 126.8 & 126.8 & 127.2 & 127.0 & 126.3 & 124.9 & 124.5 & 124.6 & 125.0 & 124.6 & 123.9 \\
\hline & 2014 & 125.4 & 125.3 & 125.5 & 125.6 & 125.5 & 125.5 & 125.8 & 126.1 & 125.8 & 126.0 & 126.5 & 125.9 \\
\hline & 2015 & 125.3 & 125.1 & 124.5 & 124.5 & * & * & 123.9 & 123.4 & 123.2 & 123.2 & 123.1 & 123.1 \\
\hline & 2016 & 123.3 & 123.3 & 123.1 & 123.2 & 125.3 & * & 124.9 & 124.6 & 125.3 & 125.3 & 123.6 & 123.7 \\
\hline \multirow[t]{7}{*}{ Well - Aviso Plateau } & 2010 & 91.8 & * & * & 90.3 & 89.8 & 90.0 & 90.1 & 90.3 & 90.0 & 90.3 & 89.7 & 90.4 \\
\hline & 2011 & 91.0 & 90.8 & 90.8 & 91.5 & 90.8 & 90.8 & 89.4 & 86.5 & 88.0 & 88.2 & 87.0 & 87.9 \\
\hline & 2012 & 88.0 & 88.6 & 87.8 & 87.7 & 87.2 & 87.4 & 87.6 & 87.9 & 87.9 & 87.8 & 87.9 & * \\
\hline & 2013 & * & * & 87.2 & 87.1 & 87.0 & 87.0 & 86.2 & 86.5 & 86.3 & 86.7 & 86.1 & 86.1 \\
\hline & 2014 & * & 88.1 & 89.2 & * & * & 88.1 & 88.1 & 88.6 & 89.2 & 89.4 & 89.3 & 89.3 \\
\hline & 2015 & 89.0 & 88.9 & 88.6 & 88.3 & 88.1 & 88.0 & 87.2 & 87.2 & 87.2 & 87.4 & 87.3 & * \\
\hline & 2016 & 87.0 & 86.9 & 86.8 & 86.5 & 86.4 & 87.0 & 85.6 & * & 85.2 & 85.0 & 84.9 & 84.8 \\
\hline \multirow[t]{7}{*}{ Well - Aramã Plateau } & 2010 & * & 66.8 & 66.9 & 63.3 & 62.9 & 65.3 & 64.7 & 64.6 & 64.3 & 61.9 & 61.6 & 61.8 \\
\hline & 2011 & 61.8 & 61.8 & 61.8 & 62.1 & 61.7 & 61.7 & 60.9 & 64.4 & 63.9 & 63.4 & 63.7 & 63.5 \\
\hline & 2012 & 63.5 & 63.5 & * & 63.7 & * & 63.4 & 63.7 & 63.7 & 65.8 & 63.4 & 63.4 & 63.4 \\
\hline & 2013 & * & 63.6 & 63.4 & 62.2 & * & 63.1 & 63.2 & 63.2 & * & $*$ & 62.9 & 62.9 \\
\hline & 2014 & 64.6 & 64.1 & 64.5 & * & 65.0 & 65.2 & 65.4 & 65.6 & 65.5 & 65.5 & 65.8 & * \\
\hline & 2015 & 66.5 & 65.8 & 64.8 & 64.5 & 64.6 & 65.0 & 64.9 & 65.0 & 65.0 & 65.0 & 64.4 & 64.4 \\
\hline & 2016 & 63.8 & 63.8 & 63.4 & 63.4 & 63.2 & 63.0 & 63.2 & 63.0 & 63.9 & 62.8 & 62.6 & 63.5 \\
\hline
\end{tabular}

${ }^{*}$ Failed data or deleted suspicious values.

between few pairs of annual averages within each of the observations sets, according to analysis of variance (ANOVA) with 95\% confidence (Table 5). These differences are attributed to the declining trend of annual rain during this same period, in addition to response to the outliers observed in some years.

The differences observed in months when there are the higher and lower water levels are attributed to three causes: annual rain distribution patterns, dimension of each plateaus and different forest preservation (Aramã and Monte Branco plateaus are original forest and Aviso plateau is mining area in environmental recovery).

The average potentiometry declined smoothly and linearly over the years on the Monte Branco Plateau, the most extensive area with a thicker lateritic profile. Also, it indicates a response time of about 1 year, where the accumulated rainfall in a given year reflects the potentiometric average levels after about 12 months. The rain effects are detected more sharply, including reproduction of the effects of precipitation outliers with less than 1-year time delay, on the Aramã Plateau, a smaller area with thinner lateritic profile. The potentiometric level in the sam- 
pling site on the Aviso Plateau resembles the Aramã Plateau, with slight difference regarding the responses to the precipitation outliers; the Aviso plateau has an intermediate dimension with changing forest cover and lateritic profile due to bauxite mining activity. Figure 6 summarizes the potentiometry results for each sampling site. It is noteworthy that the mean surface shows significant absolute values for each plateau varying from 124.0 to $128.1 \mathrm{~m}$ on the Monte Branco Plateau, from 86.0 to $90.3 \mathrm{~m}$ on the Aviso Plateau, and from 62.5 to $65.0 \mathrm{~m}$ on the Aramã Plateau.

Table 5. Analysis of Variance of the potentiometric data (Results in bold: F-value exceeds F-critical).

\begin{tabular}{ccccccc}
\hline Sample Site & Source & DF & Adj SS & Adj $M S$ & F-Value & $P$-Value \\
\hline & Factor & 6 & 169.80 & 28.30 & 24.87 & 0.00 \\
Well - Monte Branco Plateau & Error & 74 & 84.20 & 1.14 & & \\
& Total & 80 & 254.00 & & & \\
& Factor & 6 & 142.78 & 23.80 & 27.89 & 0.00 \\
Well - Aviso Plateau & Error & 67 & 57.16 & 0.85 & & \\
& Total & 73 & 199.95 & & & \\
& Factor & 6 & 60.91 & 10.15 & $\mathbf{9 . 7 1}$ & 0.00 \\
Well - Aramã Plateau & Error & 70 & 73.21 & 1.05 & & \\
& Total & 76 & 134.12 & & & \\
\hline
\end{tabular}

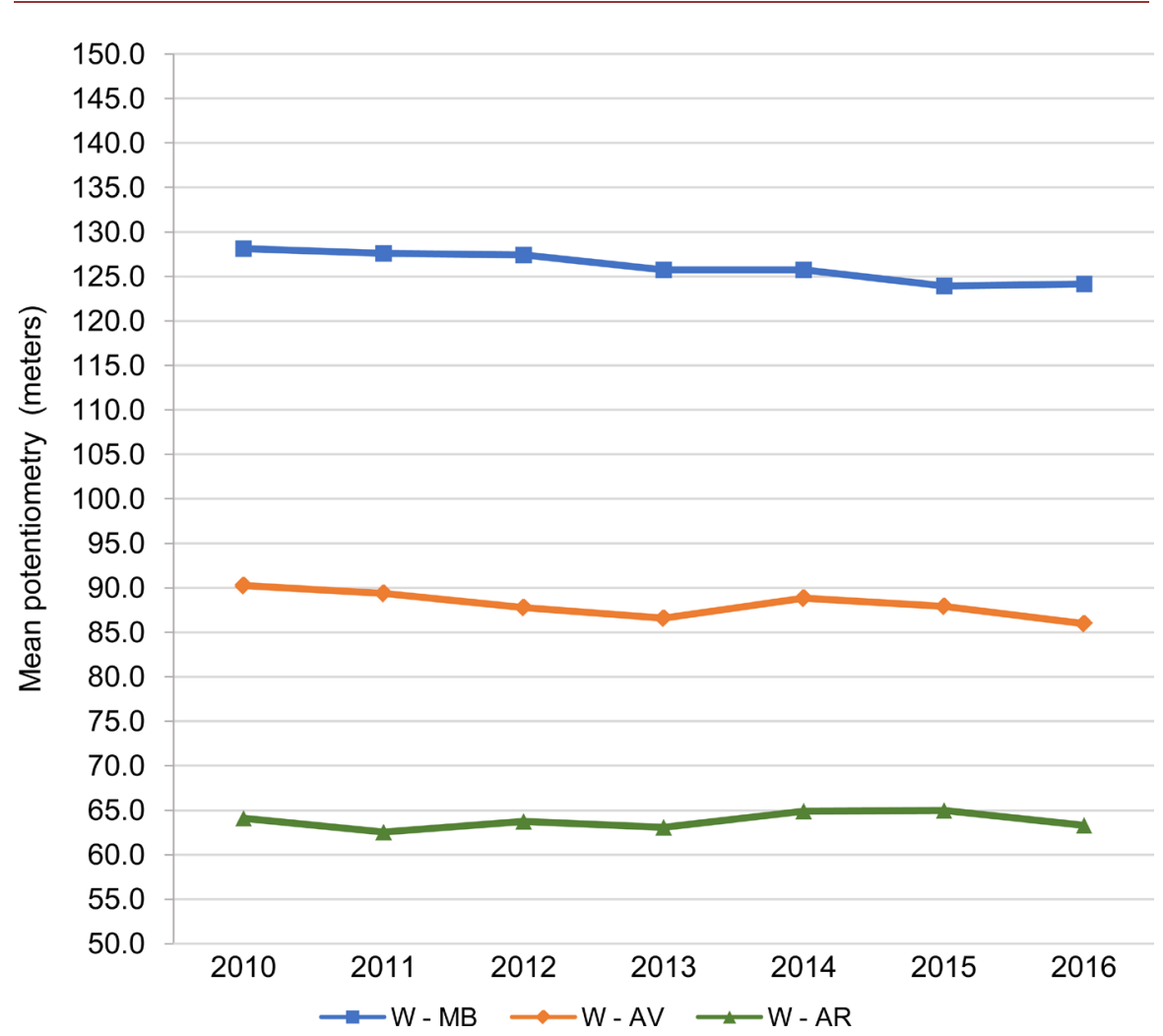

Figure 6. Annual mean potentiometry (from 2010 to 2016). 
Considering the aquifer recharge rate expressed by the seasonal fluctuations of the water table in wells $(\Delta \mathrm{h})$, the relationship with the pluviometric regime becomes more evident, especially when considering the volume accumulated in February, March and April (Figure 7).

Cross-correlations with coefficients above the significance index calculated for the 7 years of observations (0.76) confer representation to the relationship between $\Delta \mathrm{h}$ variation and accumulated annual rain (Figure 8 ). This analysis indicates noticeable rainfall influence on the recharge within the 1 year period (Lag $=0$ ), meaning that the water table elevation is associated with the accumulated rainfall in the immediately preceding period since the beginning of the rain season that contributes to recharge every year. The period between February and April is, on average, the most important for the effective recharge process.

The lowest water levels in the Monte Branco Plateau are observed between February and March and the highest, between October and December, causing the raising water levels due to recharge to last more than 6 months and indicating the high regulation capacity of this plateau, possibly due to its large area. The lowest water levels in the Aviso Plateau are seen between May and July while the raising levels occur from then on, lasting up to 3 months. It is noteworthy that this plateau is characterized by mining interventions, including, deforestation. On the other hand, the Aramã plateau displayed a random fluctuation pattern during the 7 years of monitoring; this randomness was attributed to the smaller area and, consequently, the lower capacity to regulate the underground flows.

Still according to Figure 8 , the $\Delta \mathrm{h}$ values for the wells in the Monte Branco and Aramã plateaus (W-MB and $\mathrm{W}-\mathrm{AR}$ ), areas with low human intervention, are higher than those recorded for the well in the Aviso Plateau (W-AV), an area that underwent more intensive anthropogenic change (mining and currently undergoing environmental recovery process). Azevedo, J.H. [53] reported mean

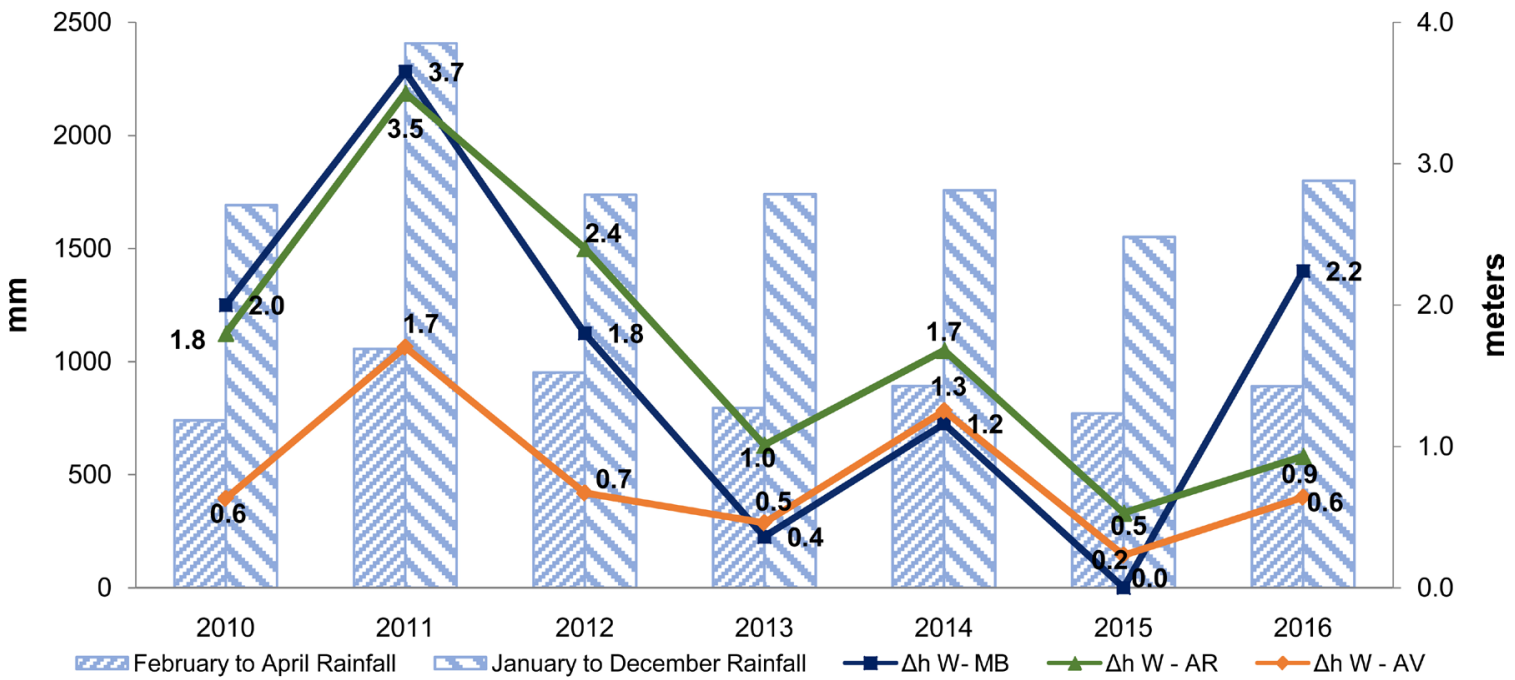

Figure 7. Rainfall and water level fluctuation in the wells $-\Delta \mathrm{h}$. Note that, despite similar rainfall recorded along the rainy season as a whole (2012-2014), the $\Delta \mathrm{h}$ curves responds to changing pluviometric patterns during the key months of February to April. 

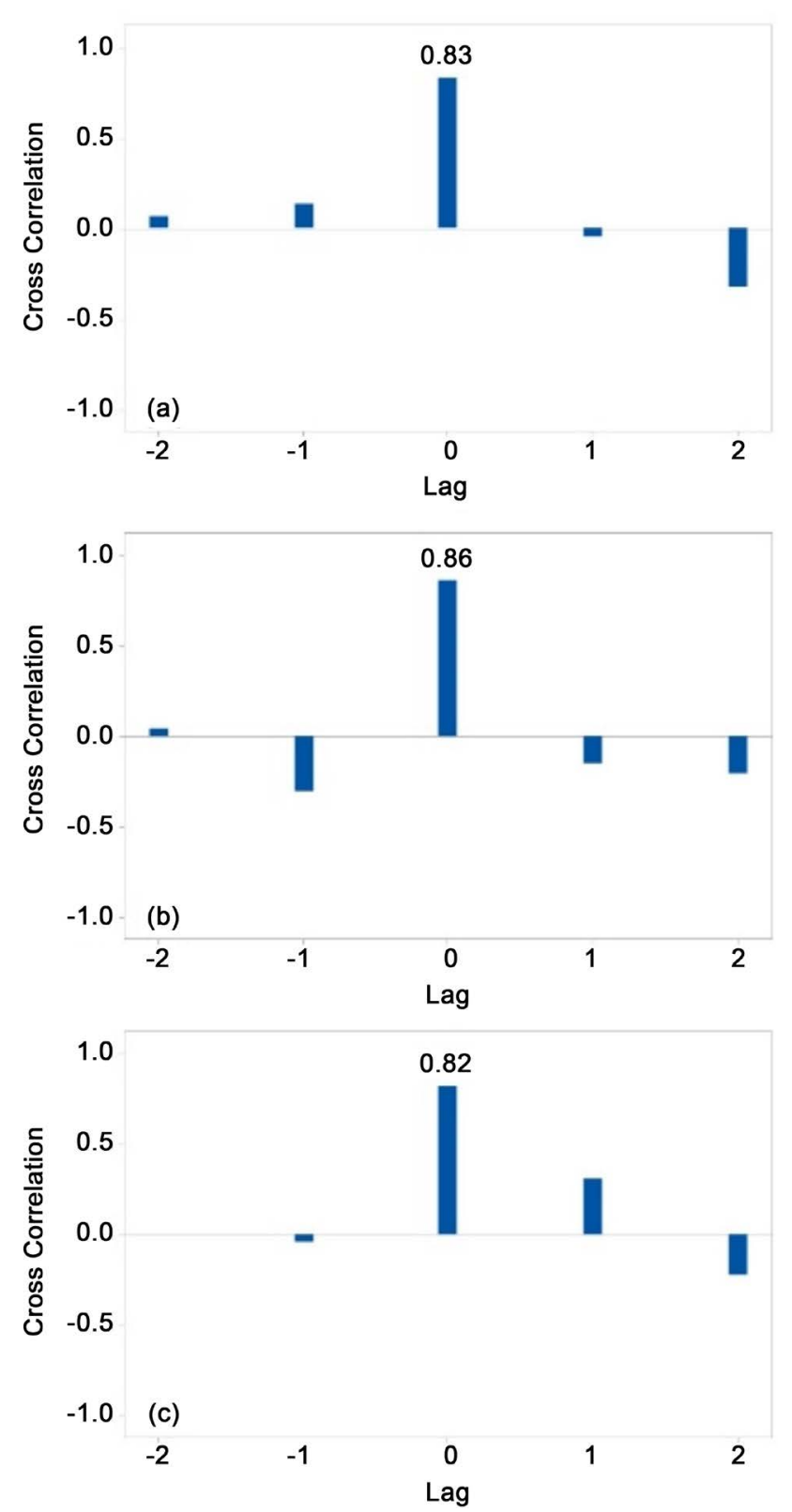

Figure 8. Cross-correlation between rainfall and water table variation ((a) Monte Branco Plateau; (b) Aviso Plateau; and (c) Aramã Plateau).

$\Delta \mathrm{h}$ values of 1.6 and 1.7 meters on the Monte Branco and Aramã plateaus, respectively, and 0.8 meter on the Aviso Plateau, almost 50\% lower than the average found for areas with preserved natural characteristics.

\section{Discussion}

The 16 years historical series for rainfall and 7 years potentiometric data are relatively small since they represent only a short period within a longer hydroclimatologic cycle. However, it allowed understanding the recharge behavior of the Alter do Chão Aquifer System as a function of rainfall regime. In the present case, a higher or lower recharge rate results from the annual accumulated rain- 
fall, as well as the frequency and magnitude of the outlier values. The correlation between the $\Delta \mathrm{h}$ values and the accumulated precipitation in the wettest months, mostly February, March and April, shows the importance of the water surplus to the recharging process. The soil field capacity ensured during the water surplus period leads to the maximum hydraulic conductivity [54], maximizing the descendent movements of moisture plumes toward the saturated zone of the aquifer.

The recharge process is particularly important from February to April since the rainy season begins in November/December. The rainfall during the subsequent months (December and January) is responsible for filling up the soil moisture to its field capacity, so that the additional humidity can migrate to the saturated zone as moisture plumes. Before the field capacity conditions are established, rainwater supplies the vegetation water demand and increases soil moisture. Satisfied all the conditions for full water movement in the soil, the precipitation volume registered from February to April determines the recharge amount of a specific year.

Azevedo, J.H. [53] explain that the recharge of the Alter do Chão Aquifer in the study area occurs by local rainfall as infiltration pulses, which can also be characterized as direct infiltration in the unconfined aquifer system, and leakage from the aquitard in the semiconfined aquifer. These conclusions are based on hydrodynamic and isotope studies.

Pearson correlation coefficients ranged from 0.75 to 0.82 for the annual $\Delta \mathrm{h}$ values in the three studied sites suggesting that the studied areas have the same hydraulic behavior, so that varying recharge magnitude and response time can be attributed to the extension and thickness of the lateritic profiles. Generally, the data indicate that the larger the plateau area the smaller the anthropogenic disturbance, and better recharge rates are observed.

Assuming a linear approximation for the recharge $(y=-0.22 x+2.26)$ and rainfall $(y=-48.87 x+2007)$ variations in the $2010-2016$ period, the mean annual reduction rates were $0.20 \mathrm{~m}$ for $\Delta \mathrm{h}$ in lateritic profiles and $50 \mathrm{~mm}$ for rainfall (considering the three research sites). Due to the greater capacity of lateritic profiles for regulating the groundwater flow [55], areas where the Alter do Chão Formation sediments outcrop and these soils are not present, the mean annual reduction rate of $\Delta \mathrm{h}$ tends to be even greater.

Furthermore, these changes are not important when considering the possibility of a new cycle with plenty rainfall. However, they become relevant and alarming in case decreasing precipitation becomes a new standard in the region, and two aspects must be particularly critical: water availability and support to eco-hydrologic processes [56] [57].

As the base flow is the product of the groundwater hydrodynamic processes [1], the potential impacts on recharge loss tend to decrease the direct discharge regimes into the river, springs and effluent streams, and consequently, reducing the discharge of the surface watercourses as well.

Under this perspective, it is essential to develop strategies for dealing with the 
potential impacts on the recharge rates of the Alter do Chão aquifer system, emphasizing the planning and execution of protective and conservation measures for the main infiltration areas, as well as artificial recharge practices to urban areas and forest preservation in rural regions.

\section{Conclusions}

The annual recharge increments must be estimated by the $\Delta \mathrm{h}$ water table values which are obtained by subtracting the higher value of the second semester from the smaller water table value of a month from the first semester.

The height of the accumulated rainwater decreased about $27 \%$ over the 16-year period (from 2002 to 2017). In general, the recharge of local aquifers decreased in a non-linear rate, but strongly correlated with the rainfall reduction.

The deforestation also affects directly the recharge pattern (as shown by the monitoring well on the Aviso Plateau), not only in terms of amount but also because the decreasing trend becomes closer to a linear fit.

Future modeling of Global Climate Changes must take into account the potential decrease of the aquifer recharge due to less rain and its consequences to the surface stream discharge rates (mainly in the low water periods). In this sense, even a small change in the rainy season (and not necessarily the total accumulated rain) may affect considerably the recharge amount.

Moreover, the statistical analysis would benefit from using longer data series so the monitoring efforts must be continued or even optimized by improving the potential for generating data from the environmental monitoring of groundwater, following those required for mining projects.

The dataset shows clearly how the aquifer recharge is controlled by rain distribution over time and space. The rains accumulated from February to April seem to be the most important to the aquifer recharge processes.

\section{Acknowledgements}

The authors are thankful to the Geosciences Institute/University of Brasília, IG/UnB for supporting the research and to the Brazilian Institute of Environment and Renewable Natural Resources for granting the qualification license. Special acknowledgement to the Brazilian Institute for Biodiversity Conservancy for authorizing the accesses to the sites and to the Rio do Norte Mining Company for providing the datasets and logistic aid.

\section{Conflicts of Interest}

The authors declare no conflicts of interest regarding the publication of this paper.

\section{References}

[1] Fetter, C.W. (2001) Applied Hydrogeology. 4th Edition, Prentice-Hall, Inc., Upper Saddle River, 598 p. 
[2] Feitosa, F.A.C., Manoel Filho, J., Feitosa, E.C. and Demétrio, J.G.A. (2008) Hidrogeologia: conceitos e aplicações. 3rd Edition, rev. e ampl. CPRM/LABHID, Rio de Janeiro, $812 \mathrm{p}$.

[3] Hirata, R. and Conicelli, B.P. (2012) Groundwater Resources in Brazil: A Review of Possible Impacts Caused by Climate Change. Anais da Academia Brasileira de Ciências , 84, 297-312. https://doi.org/10.1590/S0001-37652012005000037

[4] Foster, S., Hirata, R., Gomes, D., D'edlia, M. and Paris, M. (2002) Groundwater Quality Protection: A Guide for Water Utilities, Municipal Authorities, and Environment Agencies. The World Bank, Washington DC, 103 p. https://doi.org/10.1596/0-8213-4951-1

[5] Rebouças, A. (2002) A política nacional de recursos hídricos e as águas subterrâneas. Águas Subterrâneas, 16, 1-107.

https://doi.org/10.14295/ras.v16i1.1304

[6] Giampá, C.E.Q. and Gonçalves, V.G. (2013) Águas subterrâneas e poços tubulares profundos. 2nd Edition, rev. e atualizada, Oficina de Textos, São Paulo, 496 p.

[7] Green, T.R., Taniguchi, M., Kooi, H., Gurdak, J.J., Allen, D.M., Hiscock, K.M., Treidel, H. and Aureli, A. (2011) Beneath the Surface of Global Change: Impacts of Climate Change on Groundwater. Journal of Hydrology, 405, 532-560. https://doi.org/10.1016/j.jhydrol.2011.05.002

[8] Smerdon, B.D. (2017) A Synopsis of Climate Change Effects on Groundwater Recharge. Journal of Hydrology, 555, 125-128.

https://doi.org/10.1016/j.jhydrol.2017.09.047

[9] Dragoni, W. and Sukhija, B.S. (2018) Climate Change and Groundwater: A Short Review. Geological Society, London, Special Publications, 288, 1-12. https://doi.org/10.1144/SP288.1

[10] Zhang, E., Yin, X., Xu, Z. and Yang, Z. (2018) Bottom-Up Quantification of Inter-Basin Water Transfer Vulnerability to Climate Change. Ecological Indicators, 92, 195-206. https://doi.org/10.1016/j.ecolind.2017.04.019

[11] Anyah, R.O., Forootan, E., Awange, J.L. and Khaki, M. (2018) Understanding Linkages between Global Climate Indices and Terrestrial Water Storage Changes over Africa Using GRACE Products. Science of the Total Environment, 635, 1405-1416. https://doi.org/10.1016/j.scitotenv.2018.04.159

[12] French, R.H., Jacobson, R.L. and Lyles, B.F. (1996) Threshold Precipitation Events and Potential Ground-Water Recharge. Journal of Hydraulic Engineering, 122, 573-578. https://doi.org/10.1061/(ASCE)0733-9429(1996)122:10(573)

[13] Wu, J., Zhang, R. and Yang, J. (1996) Analysis of Rainfall-Recharge Relationships. Journal of Hydrology, 177, 143-160. https://doi.org/10.1016/0022-1694(95)02935-4

[14] Kendy, E., Zhang, Y., Liu, C., Wang, J. and Steenhuis, T. (2004) Groundwater Recharge from Irrigated Cropland in the North China Plain: Case Study of Luancheng County, Hebei Province, 1949-2000. Hydrological Processes, 18, 2289-2302. https://doi.org/10.1002/hyp.5529

[15] Nimmo, J.R., Horowitz, C. and Mitchell, L. (2015) Discrete-Storm Water-Table Fluctuation Method to Estimate Episodic Recharge. Groundwater, 53, 282-292. https://doi.org/10.1111/gwat.12177

[16] Crosbie, R.S., McCallum, J.L., Walker, G.R. and Chiew, F.H. (2012) Episodic Recharge and Climate Change in the Murray-Darling Basin, Australia. Hydrogeology Journal, 20, 245-261. https://doi.org/10.1007/s10040-011-0804-4

[17] ANA Agência Nacional de Águas (2005) Caderno de Recursos Hídricos: 
Disponibilidade e Demandas de Recursos Hídricos no Brasil. Coordenação Geral: Conejo, J.G.L. Coordenação Executiva: Mattos, B. A. ANA, Brasília, 123 p.

[18] Marengo, J.A. (2008) Water and Climate Change. Estudos Avançados, 22, 83-96. https://doi.org/10.1590/S0103-40142008000200006

[19] Swann, A.L.S., Longo, M., Knox, R.G., Lee, E. and Moorcroft, P.R. (2015) Future Deforestation in the Amazon and Consequences for South American Climate. Agricultural and Forest Meteorology, 214, 12-24. https://doi.org/10.1016/j.agrformet.2015.07.006

[20] Göpel, J., de Barros Viana Hissa, L., Schüngel, J. and Schaldach, R. (2018) Sensitivity Assessment and Evaluation of a Spatially Explicit Land-Use Model for Southern Amazonia. Ecological Informatics, 48, 69-79. https://doi.org/10.1016/j.ecoinf.2018.08.006

[21] Panday, P.K., Coe, M.T., Macedo, M.N., Lefebvre, P. and Castanho, A.D.A. (2015) Deforestation Offsets Water Balance Changes Due to Climate Variability in the Xingu River in Eastern Amazonia. Journal of Hydrology, 523, 822-829. https://doi.org/10.1016/j.jhydrol.2015.02.018

[22] Wongchuig Correa, S., Paiva, R.C.D., Espinoza, J.C. and Collischonn, W. (2017) Multi-Decadal Hydrological Retrospective: Case Study of Amazon Floods and Droughts. Journal of Hydrology, 549, 667-684. https://doi.org/10.1016/j.jhydrol.2017.04.019

[23] Kurylyk, B.L. and MacQuarrie, K.T.B. (2013) The Uncertainty Associated with Estimating Future Groundwater Recharge: A Summary of Recent Research and an Example from a Small Unconfined Aquifer in a Northern Humid-Continental Climate. Journal of Hydrology, 492, 244-253. https://doi.org/10.1016/j.jhydrol.2013.03.043

[24] Goderniaux, P., Brouyère, S., Wildemeersch, S., Therrien, R. and Dassargues, A. (2015) Uncertainty of Climate Change Impact on Groundwater Reserves-Application to a Chalk Aquifer. Journal of Hydrology, 528, 108-121. https://doi.org/10.1016/j.jhydrol.2015.06.018

[25] Kundzewicz, Z.W., Krysanova, V., Benestad, R.E., Hov, Piniewski, M. and Otto, I.M. (2018) Uncertainty in Climate Change Impacts on Water Resources. Environmental Science and Policy, 79, 1-8. https://doi.org/10.1016/j.envsci.2017.10.008

[26] ANA Agência Nacional de Águas (2015) Avaliação dos Aquíferos das Bacias Sedimentares da Província Hidrogeológica Amazonas no Brasil (escala 1:1.000.000) e Cidades Pilotos (escala 1:50.000): Hidrogeologia e Modelo Numérico da PHA Brasil. Volume 2. ANA, Brasília, $331 \mathrm{p}$.

[27] Caputo, M.V. (1984) Stratigraphy, Tectonics, Paleoclimatology and Paleogeography of Northern Basin of Brazil. PhD Thesis, University of California, Santa Barbara, $170 \mathrm{p}$.

[28] Cunha, P.R.C., Gonzaga, F.G., Coutinho, L.F.C. and Feijó, F.J. (1994) Bacia do Amazonas. Boletim de Geociências da Petrobras, 15, 227-251.

[29] ANA Agência Nacional de Águas (2005) Panorama da qualidade das águas subterrâneas no Brasil. Coordenação Geral: Conejo, J. G. L. Coordenação Executiva: Costa, M.P., Zoby, J.L.G. ANA, Brasília, 80 p.

[30] Souza, E.L., Galvão, P.H.F., Pinheiro, C.S.S., Baessa, M.P.M., Demétrio, J.G.A. and Brito, W.R.R. (2013) Síntese da hidrogeologia nas bacias sedimentares do Amazonas e do Solimões: Sistemas Aquíferos Içá-Solimões e Alter do Chão. Geologia USP. Série Científica, 13, 107-117. https://doi.org/10.5327/Z1519-874X2013000100007

[31] Caputo, M.V. and Soares, E.A.A. (2016) Eustatic and Tectonic Change Effects in the 
Reversion of the Transcontinental Amazon River Drainage System. Brazilian Journal of Geology, 46, 301-328. https://doi.org/10.1590/2317-4889201620160066

[32] Schobbenhaus, C., Campos, D.A., Derze, G.R. and Asmus, H.E. (1984) Geologia do Brasil. DNPM, Brasília, 501 p.

[33] Mendes, A.C., Truckenbrod, W. and Nogueira, A.C.R. (2012) Análise faciológica da Formação Alter do Chão (Cretáceo, Bacia do Amazonas), próximo à cidade de Óbidos, Pará, Brasil. Revista Brasileira de Geociências, 42, 39-57. https://doi.org/10.25249/0375-7536.20124213957

[34] Tancredi, A.C.F.N.S. (1996) Recursos hídricos subterrâneos de Santarém: Fundamentos para uso e proteção. PhD Thesis, Pós-Graduação em Geologia e Geoquímica, Centro de Geociências/Universidade Federal do Pará, Belém, Pará, 154 p.

[35] Aguiar, C.J.B., Horbe, M.A., Rosa Filho, S.F., Lopes, E.S., Moura, U.F., Andrade, N.M. and Diógenes, H.S. (2002) Carta hidrogeológica da cidade de Manaus. CPRM, Manaus, Internal Report, 1-4.

[36] Souza, L.S.B. and Verma, O.P. (2006) Mapeamento de aquíferos na cidade de Manaus/AM (zonas norte e leste) através de perfilagem geofísica de poço e sondagem elétrica vertical. Revista de Geologia, 19, 111-127.

https://doi.org/10.1590/S0102-261X2006000300012

[37] CPRM Serviço Geológico do Brasil (2012) Projeto Rede Integrada de Monitoramento das Águas Subterrâneas: Relatório diagnóstico Aquífero Alter do Chão no Estado do Amazonas, Bacia Sedimentar do Amazonas. CPRM, Belo Horizonte, $47 \mathrm{p}$.

[38] Lopes, M.N.G., de Souza, E.B. and Ferreira, D.B.S. (2013) Climatologia regional da precipitação no estado do Pará. Revista Brasileira de Climatologia, 12, 84-112. https://doi.org/10.5380/abclima.v12i1.31402

[39] INMET Instituto Nacional de Meteorologia (2018) Normal Climatológica 1981-2010.

http://www.inmet.gov.br/portal/index.php?r=clima/normaisClimatologicas

[40] Costa, M.L. (1991) Aspectos geológicos dos lateritos da Amazônia. Revista Brasileira de Geociências, 21, 146-160. https://doi.org/10.25249/0375-7536.1991146160

[41] Ker, J.C. (1997) Latossolos do Brasil: Uma revisão. Geonomos, 5, 17-40. https://doi.org/10.18285/geonomos.v5i1.187

[42] Horbe, A.M.C., Nogueira, A.C.R., Horbe, M.A., Costa, M.L. and Suguio, K. (2001) A lateritização na gênese das superfícies de aplanamento da região de Presidente Figueiredo-Balbina, nordeste do Amazonas. Contribuições à Geologia da Amazônia, 2, 148-176.

[43] Brandt Meio Ambiente (2007) Estudo de Impacto Ambiental-EIA: Mineração de bauxita nos platôs Bela Cruz, Aramã, Greig, Teófilo, Cipó e Monte Branco. Oriximiná, $301 \mathrm{p}$.

[44] Costa, L.M., Cruz, G.S., Almeida, E.D.F. and Poellmann, H. (2014) On the Geology, Mineralogy and Geochemistry of the Bauxite-Bearing Regolith in the Lower Amazon Basin: Evidence of Genetic Relationships. Journal of Geochemical Exploration, 146, 58-74. https://doi.org/10.1016/j.gexplo.2014.07.021

[45] Rossetti, D.F. (2014) The Role of Tectonics in the Late Quaternary Evolution of Brazil's Amazonian Landscape. Earth-Science Reviews, 139, 362-389. https://doi.org/10.1016/j.earscirev.2014.08.009 
[46] INMET, Instituto Nacional de Meteorologia (2018) Balanço Hídrico Climático. http://www.inmet.gov.br/portal/index.php?r=agrometeorologia/balancoHidricoCli $\underline{\text { matico }}$

[47] IBGE Instituto Brasileiro de Geografia e Estatística (1992) Manual Técnico da Vegetação Brasileira. Série Manuais Técnicos em Geociências 1. IBGE, Rio de Janeiro, $94 \mathrm{p}$.

[48] IBGE Instituto Brasileiro de Geografia e Estatística (2012) Manual Técnico da Vegetação Brasileira. Série Manuais Técnicos em Geociências 1. 2nd Edition, revista e ampliada. IBGE, Rio de Janeiro, 275 p.

[49] IBAMA Instituto Brasileiro do Meio Ambiente e dos Recursos Naturais Renováveis (2001) Plano de manejo da Floresta Nacional Saracá-Taquera. Mineração Rio do Norte. IBAMA, Curitiba. (paginado por capítulo)

[50] IBAMA Instituto Brasileiro do Meio Ambiente e dos Recursos Naturais Renováveis (2004) Plano de manejo da Reserva Biológica do Rio Trombetas. IBAMA, Brasília, $556 \mathrm{p}$.

[51] MRN Mineração Rio do Norte (2011) Relatórios semestrais de monitoramento ambiental da Mineração Rio do Norte-Relatório Integral Ano 201003MRN0708T REV01. STCP Engenharia de Projetos, Curitiba, 852 p.

[52] Healy, R.W. (2010) Estimating Groundwater Recharge. Cambridge University Press, New York, 245 p. https://doi.org/10.1017/CBO9780511780745

[53] Azevedo, J.H. (2019) Fluxos subterrâneos e recarga do Sistema Aquífero Alter do Chão em lateritos amazônicos: Estudo de caso em Porto Trombetas, Pará. PhD Thesis, University of Brasília, Brasília, 139.

[54] Reichardt, K. (1990) A água em sistemas agrícolas. Editora Manole Ltda, São Paulo, $188 \mathrm{p}$.

[55] Fiori, J.P.O., Campos, J.E.G. and Almeida, L. (2010) Variabilidade da condutividade hidráulica das principais classes de solo do estado de Goiás. Geociências (São Paulo), 29, 229-235.

[56] Porporato, A., O'dorico, P., Laio, F., Ridolfi, L. and Rodriguez-Iturbe, I. (2002) Ecohydrology of Water-Controlled Ecosystems. Advances in Water Resources, 25, 1335-1348. https://doi.org/10.1016/S0309-1708(02)00058-1

[57] Wahnfried, I. and Soares, E.A.A. (2012) Água subterrânea na Amazônia: Importância, estado atual do conhecimento e estratégias de pesquisa. Ciência \& Ambiente, 44, 29-40. 